\title{
Anthós
}

\section{The Sovereign Wolf: Feudal Tension and Noble Animal Changes in William of Palerne}

Charis Woodward

Portland State University

Follow this and additional works at: https://pdxscholar.library.pdx.edu/anthos

Part of the Classics Commons

Let us know how access to this document benefits you.

\section{Recommended Citation}

Woodward, Charis (2014) "The Sovereign Wolf: Feudal Tension and Noble Animal Changes in William of Palerne," Anthós: Vol. 6: Iss. 1, Article 11.

https://doi.org/10.15760/anthos.2014.185

This open access Article is distributed under the terms of the Creative Commons Attribution-NonCommercialShareAlike 4.0 International License (CC BY-NC-SA 4.0). All documents in PDXScholar should meet accessibility standards. If we can make this document more accessible to you, contact our team. 


\section{The Sovereign Wolf: Feudal Tension and Noble Animal Changes in William of Palerne}

Charis Woodward

Translated into Middle English from the twelfth century octosyllabic French Guillaume de Palerne, William of Palerne was commissioned by Sir Humphrey IX de Bohun, and composed by poet William, whom we know little about (Bunt, 11. 166). The problem with reading William of Palerne lies not within the constructed alliterative long lines, but in knowing how to read it. The intended audience for the translation of William of Palerne has been a topic of debate since the early nineteenth century. William writes his poem "in ese of Englysch men in Englysch speche" as stated in his introduction (11. 168). This sentiment is repeated at the very end of the story when the poet praises the Earl for "he let make pis mater in pis maner speche/ for hem that knowe no Frensche, ne never underston" (11. 5532-5533). Though seemingly trivial, the exact purpose these statements hold is unclear. Scholars such as Turville-Petre and Dunn have asserted these passages must illustrate the poem's intention for an unlearned audience, such as a manor staff $(40-42 ; 3)$. TurvillePetre further states that the poem's production was possibly intended to sedate Humphrey IX's established retinue by assuring them of "the benevolent interest of their absent overlord." He also emphasizes the improbability that the composition was done "for the instruction and delight of the Earl himself" (The Alliterative Revival, 41). Still, others contrastingly argue the possibility that the Earl personally could not speak French and therefore ordered its translation out of necessity and private desire (Bunt, 18). This claim of linguistic ignorance seems farfetched, as many scholars such as Salter illustrate that the libraries 
of fourteenth century nobles were well stocked in both French and Latin texts (150). More likely, the reasoning behind the composition of William of Palerne is intermingled somewhere between the two schools of thought and therefore was intended for a boarder audience than what was first imagined by previous scholars.

Whether William of Palerne was meant to be didactic toward the lower class, or reassuring for the English noblemen, this argument of intended audience has further implications not only for the poem, but also the state of fourteenth century England. The debate is essentially one of nationalism or transnationalism: should this poem be read as beneath the nobility (by being written in Middle English) or should it be read as a conscious declaration of Englishness? Instead of insisting on one reading, perhaps this text should be viewed as an exemplum of the shifting feudal and nationalist ideals of the fourteenth century. This mixed and changing view of the world can be experienced in the visual transformations of the poem. These changes mainly deal with the human-animal-becomings being forced to interact within courtly environments as well as the natural, and explore the naturalization of a changing aristocratic class. The social tension, seen throughout the romance of William of Palerne (hereafter, William), is exemplified in the poem's rendering of these noblemen through their occupation of the liminal space between these natural and "other" worlds.

The bulk of William revolves around the dual animaltransformations plots of the male protagonists. However, the poem's concerns lay within the multiple versions of visual transformation, as well as the recognition (or lack thereof) behind them. The term "visual" is used here because, though transformations such as the werwolf seem complete, it is apparent that only his physical being remains changed. His intellect, along with any errant animality, is completely intact and natural to his original aristocratic state. All transformations happen on the surface level; they act as an optical change that can be simulated by removing or adding clothes, and indeed, many are just that. 
The initial visual disguise introduced to William's audience occurs when the emperor of Rome encounters William in the woods. Upon first sight, the emperor knows the boy is no commoner. The vision of the exceptional child forces the emperor to question whether the child is "of feyrye" (11. 230). This scene importantly takes places in a forest. Forests represent an otherworldly place, the places of myths and fairytales, as well as a royal place. In the fourteenth century, the forests belonged to the monarchy, making it illegal for commoners to hunt within them. Therefore, the only rightful inhabitants of these woods were the beasts and sovereign gamesmen. The claim of the child's mythical being is not then farfetched. Being apparent he elicits no beast, the child could likely be either royalty or fae, but (recognizably for the emperor) not common. It takes the aristocratic blood of the emperor, or the supernatural sovereignty of the werwolf, to distinguish the boy from the unintentional disguise of his peasant's clothes.

The same scene, where the emperor finds William, the poet depicts another sort of disguise: the artifice of the common intellect. When conversing with the cowherd, William's adopted father, the emperor notices the man's manner of speech. The cowherd warns William of the ways of court, his own father having been a "kourteor," after which William bids his friends farewell (11. 342, 36067). The juxtaposition of the cowherd giving courtly advice while also being a person of such a common name gives the emperor "gaynliche god game" (11. 370). As Schiff points out, "he [the emperor] finds it amusing that lower life forms could master human activity" (425). The affirmation of the cowherd being lower than human interestingly places the peasant class lower than the animal kingdom, which are either treated with the respect of an equal, or as a necessary sustenance for the nobility (food or clothing). If we accept Salter's declaration that the representation of medieval animals is not used to understand animals themselves, but as a mirror upon which to look at the structure of humanity, it is apparent that the mirror is only focused 
on one social structure: the aristocracy (Holy and Noble Beasts, 3). In many ways, the peasants of William are more capable of the role of animal (or mirror). Through this exchange between the cowherd and the king, the reader learns not only of the royal disgust for such a base man using courtly knowledge, but it also reveals an anxious awareness in the conventionality of the cowherd's advice; the emperor is introduced to the idea that courtly ethics are possibly learned, and govern the behaviors of both nobles and non-nobles alike (Schiff, 425). This anxiety coincides with the House of Lords' parliamentary apprehensions within the fourteenth century. Until this era, the aristocracy had full feudal control over the peasant class, and parliamentary control over taxation (Roberts, 169-171). By the 1350 's, however, the newly recognized House of Commons gained enough power to have equal say in the matters of royal advisement and appropriate taxation.

Whisked away to court from his unseemly peasant's life, William eventually assumes another disguise. When William's love, Melior, is betrothed to another, the two decide to escape the confines of the court and, with the help of a magical friend Alisaundrine, they assume the appearance of two white bears (11. 1660-1704). The uniqueness behind what seems to be a fairly common medieval trope lies within the normality, if bizarrely so, of the transformation. The white bear hides are sewn over the lovers' elite clothing, creating a layer of animalistic-seeming over a layer of proper courtly appearance. Alisaundrine explains to William and Melior that these disguises will help them pass undetected by feudal society, stating "noper clerk not knizt nor of cuntre cherle" could see through their disgueises (11. 1676). Alisaundrine seems to have left out the high nobility in her list. This omission implies an innate sense of knowing prescribed to the nobly born, as earlier witnessed in the emperor's ability to see the nobility behind William's common clothes. The sovereign characters maintain a power of observation that others are not granted within the poem. Therefore, the act of retaining their aristocratic social status by 
keeping their clothes must be done for either an inner cause, or for the benefit of the lower class.

This reluctance to rid themselves of their aristocratic symbols may be purely a sign of modesty, but the humility instigated has further social implications. There are two other times the issue of clothing (or removal of it) creates aristocratic social barriers. The first instance occurs while the lovers are in the woods on the run. Their bear disguises rendered useless, William pleads with Melior to "dof blive pis bere-skyn and be stille in pi clopes" (11. 2343). William is aware that neither her beauty nor grace, nor her femininity or humanity, will save her from the intruding poachers. The symbol of her nobility alone can stop an impeding attack (Schiff, 432). In this way, the "comly clopes" are more than a sign of modesty, but a key to pass between the two worlds of hidden animal and courtly lady. Outside of the practicality of noble clothing as a tool for recognition, such attire is also used to elevate courtly morals.

The character that most immediately occupies the liminal space of the natural and the other is Alphouns the werwolf. In order to understand the nature of the beast, the problem of a wolf's humanity needs be resolved. As Crane demonstrates through her examination of Marie de France's Bisclavret, Alphouns belongs to a small group of mutant-wolf transformation myths. Alphouns, like Bisclavret's wolfprotagonist, has no apparent dichotomy between man and wolf: they neither relay fully man, nor beast. In her essay "Elements of Magic in the Romance of William of Palerne," Kate Tibbals inspects the different werewolves found within folklore. She describes the three main types: the werwolf-by-nature, the "Teutonic" werwolf, and the werwolf-by-magic (7-10). Of the three, only the last involves an involuntary transformation, and where Alphouns most accurately fits, as his becoming-animal results from a magic curse. However, within all of Tibbal's categories, all changes are complete. When a man exists in his human state, he is fully human, but when he lives in his wolf-state, he becomes wolf. Because his resurrection as man results 
at the end of the story, it is difficult to make any claims about Alphouns the man, but his years as a wolf show the reader a unique duality within his being-wolf. This duality, however, is not inherent to Alphouns because of his wolf-shape. Instead, the image of the animal remains anthropomorphized into a noble and logical beast. Alphouns not only displays his wit, but he also retains all the cultural milieu of an aristocrat.

At the end of the poem, Alphouns is propositioned with the ability to be transformed back into a human. While ready to be changed back into his human form, the wolf refuses until he takes leave to his bedchambers (11. 4423-4). The prospect of being man, but not clothed, appears worse than staying a beast. Alphouns' abashed aversion to nudity both signals his humility as well as a complete divergence from his disguise as wolf. When visually a wolf, his royalty was not jeopardized, however, the act of nudity becomes baser than animal imagery and cannot not reflect his sovereignty. Alphouns' modesty distinguishes Alphouns as a man of morals within a wolf. Crane proposes that, "When animals graduate from irrelevance to the status of beings in relation to which the human recognizes itself, animals come inside the circle of ethical consideration" (52). At the danger of anachronistically applying modern ethics to the medieval, Alphouns' assimilation of courtly ethics does not enable the audience ethically to consider him as the wolf, but to consider the wolf as man. The sovereignty within Alphouns is perpetuated regardless of his fur.

The humanity within Alphouns-as-wolf cannot be disputed. Satisfying what Crane dubs the "rational wolf" and Tibbals the "sympathetic wolf," Alphonse escapes the stereotypic rituals of lycanthropy. Instead of fulfilling the typical role of the wolf as childmurderer, Aplhouns plays the role of caretaker to William, both as a child and later during William and Melior's flee. As the lovers are hiding in the wood, Alphonse makes sure they are well fed bringing them "bred," "bouf," and "tvo flakets ful of ful fine wynes" (11. 1868- 
1898). Schiff illustrates the cultural role Alphouns plays in sustaining the noble status of the outcast lovers. Schiff writes:

The werewolf's furnishing of the lovers with cultural necessities during their woodland stay both furthers the poem's naturalization of aristocratic habits of consumption, and demonstrates Alphonse's status as a human-animal hybrid who has avoided the total metamorphosis into animality. (426)

Even while away from court, and away from their human identity, their wolf-guide allows the couple to engage in the aristocratic behaviors of their custom. Alphouns' extensive knowledge of what a lord and a lady should be fed, fine wine and cooked meat, despite him having left his own court as a young child, asserts the idea that nobility is not an acquired state, but a birth right.

However, William's sovereign right to eat well as an outlaw comes at a price to the common people. Alphouns' sympathetic nature reaches only as far as the aristocracy, as he inflicts violence on numerous laypeople throughout the course of the lovers' travel. On one such occasion, Alphonse realizes the wolf archetype of the babysnatcher. As the lovers face the threat of discovery, Alphouns creates a distraction by swiftly catching the "provost sone" within his mouth and leading the hoard of hunters away (11. 2372-2385). The poet William interjects his praise, "but godli, as God wold, swiche grace bitidde,/ pe werwolf was war and wist of here tene" (11. 2368-2369). This exultation of violence reveals what Schiff deems as "the predatory habits of an aristocracy that brutally exploits laborers" (425). The fact that the animal receives such profound respect while the peasant class, who are doing their perceived civic duty in finding the lost princess, are treated as at best laughable and at worse deserving of aggression speaks to the inherent class struggle of the fourteenth century. 
Anthós, Vol. VI, Issue 1

Aristocratic sympathies toward animal aggression extend further when Alphouns tries to attack his step-mother, the Queen of Spain. The wolf's violent intentions are known- "to do hire to pe dethe deliverli" (11. 4334). Because the wolf's intelligence is recognizedthe poet William uses the phrase "witty wolf" on various occasionshis hostility is not met with anger, but instead questioning. William detains the wolf and kindly tells him, "mi swete dere best, trust to me as treuli as to pin owne broper" (11. 4359-60). The wolf answers William with a bow and a kiss (11. 4377). It is upon seeing these two actions, the brute force and communion with William, the Queen of Spain submissively agrees to transform the wolf back into Alphouns the man. The hybridity of animal aggression and linguistic techniques enforces the inherent sovereign power of Alphouns. Schiff asserts Alphouns' gestures literally and figuratively point to his humanity and social status (426).

Thus the animalistic tendencies of Alphouns cannot be solely attributed to his magical transformation. This type of hybridized aggression comes forth in the humanized-wolf seen in William at battle. Out of loyalty to his animal friend, William chooses the wolf as his insignia for his royal coat of arms. From this point on, William is referred to by his enemies at war as "the wolf" or "the man with the wolf shield" (e.g. 11. 3832). Just as the wolf is culturally anthropomorphized, William is animalized on the battlefield. He essentially loses his identity as man and is transferred into the realm of militant beast, a space he alone occupies. He is unbeatable in battle because of his animal aggression and noble blood. In her book Holy and Noble Beasts, Salter ponders the effects of the mutual relationship between sovereign and beast. Salter concludes that one cannot do harm to the other (86). In assuming both identities, William as King and William as wolf, he has become beyond defeat, beyond the corporeal bounds of the common people and entered into a state of "in between." 
To the audience of William, aristocratic or common, this depiction of battle would hold much meaning. Militaristic tensions of feudal England were growing exponentially in the fourteenth century. The basis for feudalism was to ensure a martial cohesion throughout England. In practice, it allowed noblemen a convenient reasoning behind their high status, but with the technological advancements of the longbow, this role as protector became outdated and inefficient. Peasants with little training could pierce the armor of the mounted knights with the use of this new weapon, which created vast social tensions between the feudal structures (Roberts, 164-169). Though war is described as creating a barren, desolate city out of the once thriving Sicily, these aristocratic worries are snuffed out in the action sequences within William. He does not only become animal, he becomes infallible: an aristocrat worthy of his armor.

The visual disguises of the nobility illustrate their ability to move between spaces that are otherwise off limits to the general public. Because the commoner's ineptness at recognition, and the mutual understanding between animals and nobles, the transformations of the aristocracy allow their continued right to sovereignty under a veil of anonymity. Nonetheless, these changes also explore the superficiality of the positions of those nobles. The use of magic and costumes points to a certain artifice of the aristocracy that had fueled the growing tensions during the Hundred Years War and would eventually lead to the Peasant's Revolt of 1381. The primal exemption of the sovereignty from laws and defeat depicted with William showcase the desires of a strained social class. In his essay "The English Alliterative Revival and the Literature of Defeat," Charles Moorman states the cause of the Alliterative Revival as stemming from the turmoil of a socially chaotic time (90). One of the earliest romances of the Alliterative Revival, William of Palerne embodies the chaos of the time through a riveting tale of animal changes, heroic battles, mistaken identities, and courtly love. 
Anthós, Vol. VI, Issue 1

\section{Bibliography}

Bildhauer, Bettina, and Robert Mills. The Monstrous Middle Ages. Cardiff: U of Wales P, 2003. Print.

Bunt, G H. V. William of Palerne: An Alliterative Romance. Groningen: Bouma's Boekhuis, 1985. Print.

Bynum, Caroline W. "Metamorphosis, or Gerald and the Werwolf." Speculum 73.4 (1998): 987-1013. JSTOR. Web. 5 June 2013.

Crane, Susan. Animal Encounters: Contacts and Concepts in Medieval Britain. Philadelphia: U of Pennsylvania P, 2013. Print.

Dunn, Charles W. The Foundling and the Werwolf: A Literary-Historical Study of Guillaume De Palerne. Toronto: U of Toronto P, 1960. Print.

Heng, Geraldine. Empire of Magic: Medieval Romance and the Politics of Cultural Fantasy. New York: Columbia UP, 2003. Print.

Lawton, David, ed. Middle English Alliterative Poetry and Its Literary

Background: Seven Essays. Cambridge: D. S. Brewer, 1982. Print.

Madden, Frederic. The Ancient English Romance of William and the Werwolf.

New York: B. Franklin, 1970. Print.

"Middle English Romances." Middle English Romances. U of York, 2012. Web.

1 May 2013.

Moorman, Charles. "The English Alliterative Revival and the Literature of Defeat." Chaucer Review 16.1 (1981): 85-100. JSTOR. Web. 5 June 2013.

Roberts, Clayton, and David Roberts. "Chapter 7: War and Crisis." A History of England: Prehistory to 1714. Fifth ed. Vol. 1. Upper Saddle River, NJ: Pearson Education, 2009. n. pag. Print.

Salisbury, Joyce. The Beast Within: Animals in the Middle Ages. Hoboken: Taylor and Francis, 2012. Ebook Library. Web. 5 Jun. 2013.

Salter, David. Holy and Noble Beasts: Encounters with Animals in Medieval Literature. Woodbridge, Suffolk, UK: D. S. Brewer, 2001. Print.

Schiff, R.P. "Cross-channel Becomings-Animal: Primal Courtliness in Guillame De Palerne and William of Palerne." Exemplaria 21.4 (2009): 418-438. Print.

Skeat, Walter W. The Romance of William of Palerne: Or, William and the Werwolf, Together with a Fragment of the Alliterative Romance of Alisaunder. Millwood, N.Y: Kraus Reprint Co., 1981. Print.

Smith, Kirby F, and M. D. Learned. "An Historical Study of the Werwolf in Literature." PMLA 9.1 (1893): 1-42. JSTOR. Web. 10 July 2014.

Tibbals, Kate W. "Elements of Magic in the Romance of William of Palerne." Modern Philology 1.3 (1904): 355-371. JSTOR. Web. 5 Feb. 2013.

Turville-Petre, Thorlac. The Alliterative Revival. Cambridge: D.S. Brewer, 1977. Print.

White, Hugh. Nature, Sex, and Goodness in a Medieval Literary Tradition. Oxford: 
Charis Woodward

Oxford UP, 2000. Print. 